ISGOP sita 15

1. EDT 616494

\begin{tabular}{|l|l|}
\hline $\begin{array}{l}\text { 2. To: (Receiving Organization) } \\
\text { Distribution }\end{array}$ & $\begin{array}{l}\text { 3. From: (Originating Organization) } \\
324 \text { Stabilization Projects }\end{array}$ \\
\hline $\begin{array}{l}\text { 5. Proj/Prog./Dept/Div.: } \\
19300\end{array}$ & $\begin{array}{l}\text { 6. Design Authority/Design Agent/Cog. Engr. } \\
\text { J. E. Ham }\end{array}$ \\
\hline
\end{tabular}

8. Originator Remarks:

For approval and release

3. From: (Originating Organization)

11. Receiver Remarks:

11A. Design Baseline Document? (O) Yes $\bigcirc$ No
4. Related EDT No:
N/A
7. Purchase Order No:
$\mathrm{N} / \mathrm{A}$
9. Equip./Component No.
$\mathrm{N} / \mathrm{A}$
10. System/Bidg./Facility:
324 Building
12. Major Assm. Dwg. No.:
$\mathrm{N} / \mathrm{A}$
13. Permit/Permit Application No.:
$\mathrm{N} / \mathrm{A}$

14. Required Response Date:

\begin{tabular}{|c|c|c|c|c|c|c|c|c|c|c|c|c|c|}
\hline & & & & & & & & & & $12 /$ & /3/99 & the & \\
\hline 15. & & & & DATATR & INSMITTE & & & & & (F) & (G) & (H) & (I) \\
\hline $\begin{array}{l}\text { (A) } \\
\text { Item } \\
\text { No. }\end{array}$ & & (B) Docume & nt/Drawing No. & $\begin{array}{l}\text { (C) Sheet } \\
\text { No. }\end{array}$ & (D) Rev. & (E) $\mathrm{T}$ & itte or $\mathrm{D}$ & escript & ion of Data Transmitted & $\begin{array}{c}\text { Approval } \\
\text { Desig- } \\
\text { nator }\end{array}$ & $\begin{array}{l}\text { 1. Reason } \\
\text { for Trans- } \\
\text { mittal }\end{array}$ & $\begin{array}{c}\text { Origi- } \\
\text { nator } \\
\text { Dispo- } \\
\text { stion }\end{array}$ & $\begin{array}{l}\text { Receiv- } \\
\text { er } \\
\text { Dispo- } \\
\text { sition }\end{array}$ \\
\hline 1 & HNF & -4412 & & Al1 & 0 & Fun & ction & al $\mathrm{D}$ & esign Criteria & ESQ & 2 & 1 & 1 \\
\hline & & & & & & 324 & Buil & ding & Liquid Waste & & & & \\
\hline & & & & & & Hanc & dling & Sys & tem & & & & \\
\hline & & & & & & & & & & & & & \\
\hline & & & & & & & & & & & & & \\
\hline & & & & & & & & & & & & & \\
\hline & & & & & & & & & & & & & \\
\hline 16. & & & & $\therefore$ & & & KEY & & & & & & \\
\hline Appro & val Des & ignator $(F)$ & & ason for Trar & Ismittal (G) & & & & & sposition ( & (H) \& (l) & & \\
\hline É & $\begin{array}{l}\text { Q, D } \\
\text { WHC } \\
\text { Sec. } 1\end{array}$ & $\begin{array}{l}\text { OR N/A } \\
\text { CM-3-5, } \\
2.7)\end{array}$ & $\begin{array}{l}\text { 1. Approval } \\
\text { 2. Release } \\
\text { 3. Information }\end{array}$ & $\begin{array}{l}\text { 4. Review } \\
\text { 5. Post-Re } \\
\text { 6. Dist. (Re }\end{array}$ & $\begin{array}{l}\text { view } \\
\text { ceeipt Ackn }\end{array}$ & now. $R$ & equired & & $\begin{array}{l}\text { 1. Approved } \\
\text { 2. Approved w/comme } \\
\text { 3. Disapproved w/comr }\end{array}$ & ment & $\begin{array}{l}\text { 4. Reviewt } \\
\text { 5. Reviewe } \\
\text { 6. Receipt }\end{array}$ & $\begin{array}{l}\text { ed no/con } \\
\text { ed w/com } \\
\text { acknowle }\end{array}$ & $\begin{array}{l}\text { mment } \\
\text { mment } \\
\text { ledged }\end{array}$ \\
\hline 17. & & & & (Se & $\begin{array}{l}\text { SIGI } \\
\text { e Approval }\end{array}$ & $\begin{array}{l}\text { NATUF } \\
\text { IDesig }\end{array}$ & $\begin{array}{l}\text { RE/DIS } \\
\text { Rator fo }\end{array}$ & $\begin{array}{l}\text { TRIBU] } \\
\text { ir requi }\end{array}$ & $\begin{array}{l}\text { rion } \\
\text { red signatures) }\end{array}$ & & & & \\
\hline $\begin{array}{l}\text { (G) } \\
\text { Rea- } \\
\text { son } \\
\end{array}$ & Disp & (J) Name & (K) $\mathrm{Sin}$ & (L) $\mathrm{D}$ & ate $(M)$ & MSIN & \begin{tabular}{|l|} 
(G) \\
Rea- \\
son \\
\end{tabular} & $\begin{array}{c}(H) \\
\text { Disp. }\end{array}$ & (J) Name & & (L) & Date & (M) MSIN \\
\hline 1 & 1 & Design Aut & hority D. S. I & $\mathrm{umi}_{\mathrm{A}} \mathrm{t}$ & aksimin & -02 & 1 & I & R. L. Hobart & & & $13 \mid 94 \mathrm{~L}$ & $1-08$ \\
\hline & & Design Age & nt $\quad N / A$ & & & & 1 & 1 & T. L. Erickson & & $2 \quad-1$ & $2 \operatorname{arat}$ & $1-02$ \\
\hline 1 & 1 & Cog. Eng. & J. E. Ham & tem 11/2 & $9 / 99$ L1 & -08 & 1 & 1 & D. o. Jenkins & $x y$ & M 12 & reify & $1-01$ \\
\hline 1 & 1 & Cog. Mgr. & J. G. Rido & e thede & all ${ }^{12} 1^{2}$ & 799 & 1 & 1 & w. K. Lacey $\mathbb{Z}$ & & $2 y$ & $\begin{array}{r}10819 \\
27 \mathrm{~L}\end{array}$ & $9-08$ \\
\hline 1 & 1 & QA & H. E. Rew & in 1 & $\left.47\right|^{9} q_{1}$ & -06 & 1 & 1 & $C, M, K R O N \cup A L L$ & & 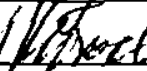 & $126.5 \%$ & $\mid q_{i} \leq 1-0$ \\
\hline 1 & 1 & Safety & S. A. Nor & ba & $\log ^{12-6}$ & & & & & & & & \\
\hline 1 & 1 & Env. & D. E. Rasn & enmusen & $B / 4 / 9 ; L 1$ & .04 & & & & & & & \\
\hline 18. & & & 19. & & & & 20. & & & 21. $\mathrm{DOE}$ & $\begin{array}{l}\text { APPROVA } \\
\text { INo. } \quad 1\end{array}$ & $\begin{array}{l}\text { AL (if requ } \\
V / \mathcal{A}\end{array}$ & uired) \\
\hline & $\leq \mathscr{A}$ & $m$ & $12 / 15 / 92$ & & & & & & $415 / 49$ & & Approved & & \\
\hline $\begin{array}{l}\text { Signa } \\
\text { Origi }\end{array}$ & $\begin{array}{l}\text { ture of } \\
\text { lator }\end{array}$ & & Date & $\begin{array}{l}\text { ed Represen } \\
\text { iving Organiz }\end{array}$ & $\begin{array}{l}\text { ative } \\
\text { ation }\end{array}$ & Date & & $\begin{array}{l}\text { in Auth } \\
\text { izant } M\end{array}$ & $\begin{array}{l}\text { orityl } \\
\text { lanager }\end{array}$ & $\bigcirc$ & $\begin{array}{l}\text { Approved } \mathrm{v} \\
\text { Disapprove }\end{array}$ & v/comme & ints \\
\hline
\end{tabular}

BD-7400-172-2 (10/97)

BD-7400-172-1 


\section{DISTRIBUTION SHEET}

To

Distribution

Project Title/Work Order

Functional Design Criteria 324 Building Liquid waste Handling system
From

324 Stabilization Project
Page 1 of 1

Date

EDT No. 616494

ECN No.

\section{Name}

Central Files

N. F. Barilo

J. M. Barnett

G. R. Chiaramonte

T. L. Erickson

B. G. Foreman

S. D. Halstead

J. E. Ham

R. L. Hobart

A. M. Horner

D. O. Jenkins

J. M. Kisielnicki

C. M. Kronvall

W. K. Lacey

R. M. Millikin

S. A. Norling

B. B. Peters

A. L. Prignano

D. E. Rasmussen

H. E. Rew

J. G. Riddelle

H. W. Ruby

D. H. Sandoz

D. S. Takasumi

DOE Reading Room

\begin{tabular}{c|c|c|c|c} 
MSIN & $\begin{array}{c}\text { Text } \\
\text { With All } \\
\text { Attach. }\end{array}$ & Text Only & $\begin{array}{c}\text { Attach./ } \\
\text { Appendix } \\
\text { Only }\end{array}$ & $\begin{array}{c}\text { EDT/ECN } \\
\text { Only }\end{array}$ \\
\hline
\end{tabular}

B1- 07

L6 - 57

L1-05

H3 -28

L1 - 02

L1-01

L1-02

L1-08

$\mathrm{L} 1-08$

L6 - 57

L1-01

L1-04

L1-08

L1 - 08

L0-31

L6-57

H1 - 11

G1- 30

L1-04

L1-06

L1-02

L6 - 57

L1-06

L1-02

H2-53

$\mathrm{X}$

X

$x$

$x$

$x$

$\mathrm{X}$

X

$x$

$\mathrm{x}$

$x$

$\mathrm{x}$

$\mathrm{x}$

$\overbrace{x}^{x}$

$\mathrm{x}$

$\mathrm{x}$

$\mathrm{X}$

$\frac{x}{x}$

$\mathrm{X}$

$\mathrm{x}$

$\frac{x}{x}$

$\frac{x}{x}$

$\mathrm{x}$

$x$ 


\title{
324 Building Liquid Waste Handling System Functional Design Criteria
}

\author{
J. E. Ham \\ Fiuor Daniel Hanford, Inc. \\ Richland, WA 99352 \\ U.S. Department of Energy Contract DE-AC06-96RL13200

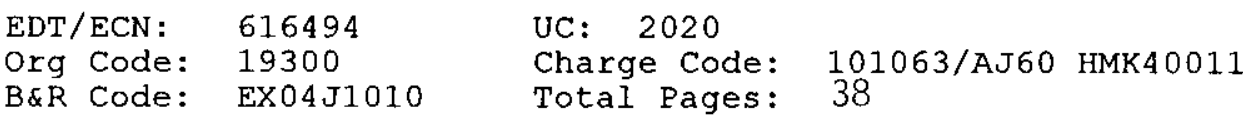

Key Words: 324 Building, 324 Facility, liquid waste, LWHS, Functional Design Criteria, FDC

Abstract: The 324 Building in the 300 Area of the Hanford Site, is preparing to design, construct, and operate the Liquid Waste Handling system (LWHS). The system will include transfer, collection, treatment, and disposal of radiological and mixed liquid waste which will be generated during the stabilization of rooms, cells, tanks, and vaults. This document defines the design criteria necessary for a safe and operable system.

TRADEMARK DISCLAIMER. Reference herein to any specific commercial product, process, or service by trade name, trademark, manufacturer, or otherwise, does not necessarily constitute or imply its endorsement, recommendation, or favoring by the United states Government or any agency thereof or its contractors or subcontractors.

Printed in the United States of America. To obtain copies of this document, contact: WHC/BCS Document Control Services, P.O. Box 1970, Mailstop H6-08, Richland WA 99352, Phone (509) 372-2420; $\operatorname{Fax}$ (509) 376-4989.
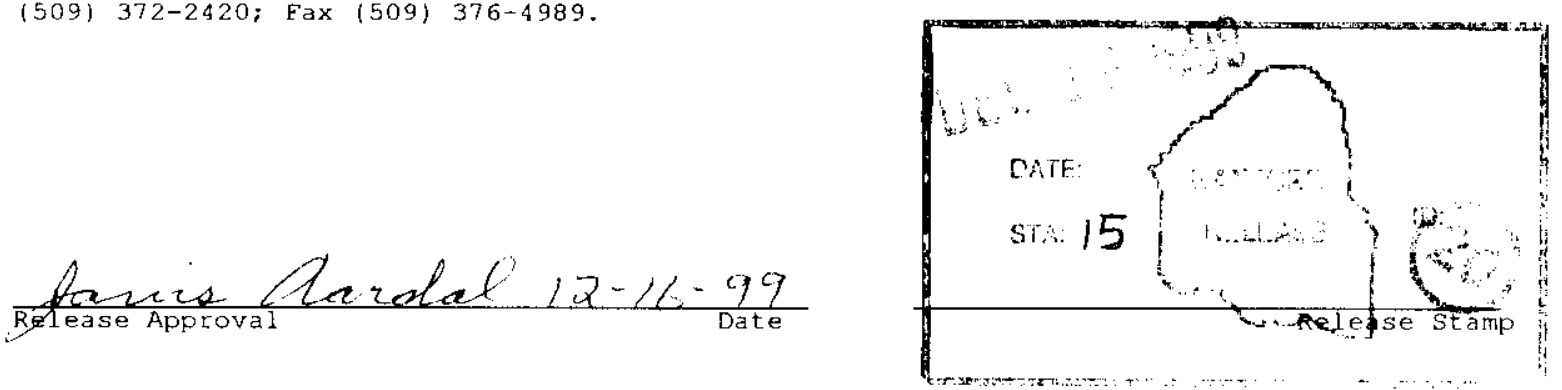

\section{Approved for Public Release}




\section{HNF-4412, Rev. 0}

\section{Table of Contents}

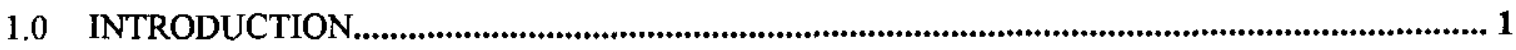

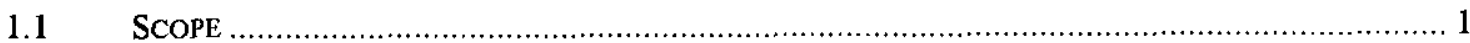

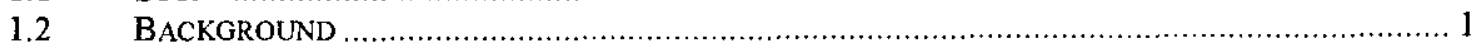

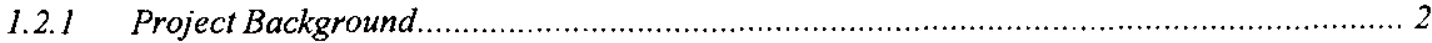

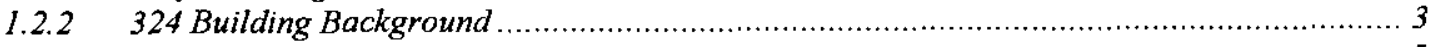

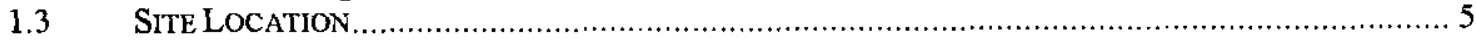

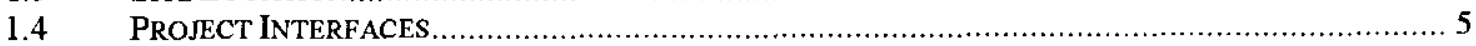

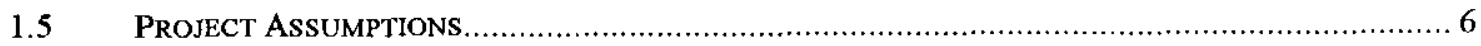

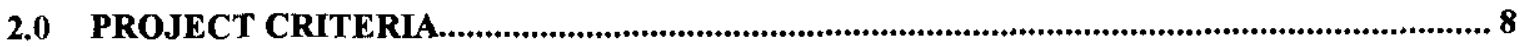

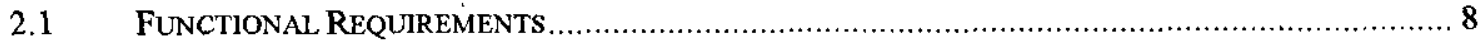

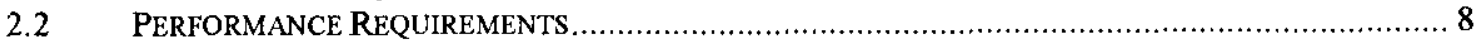

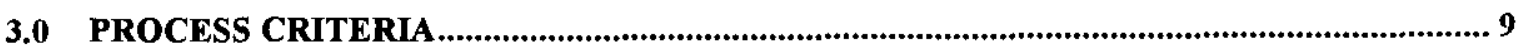

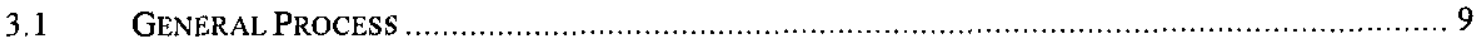

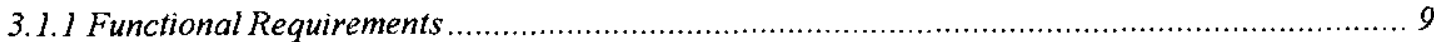

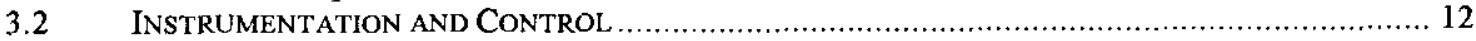

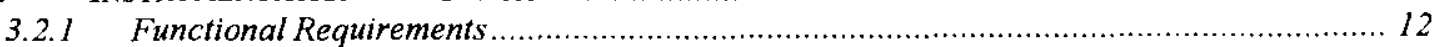

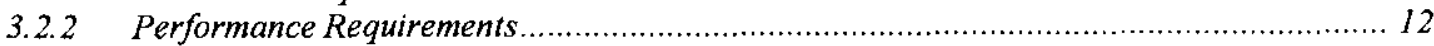

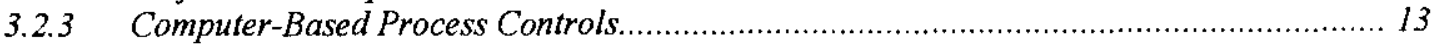

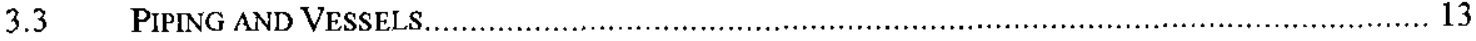

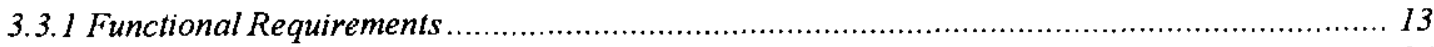

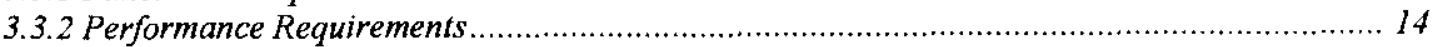

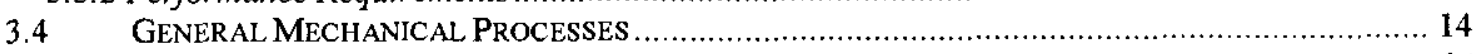

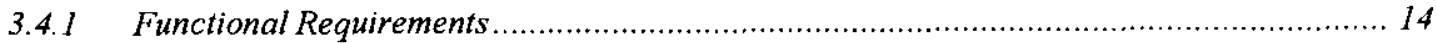

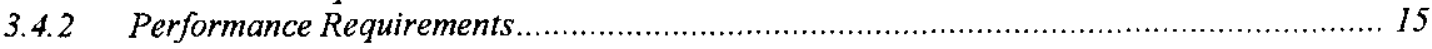

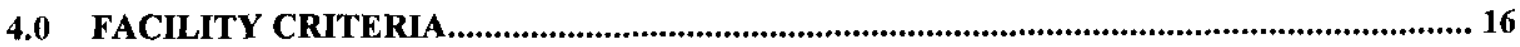

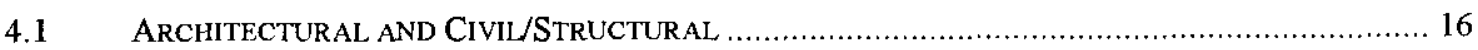

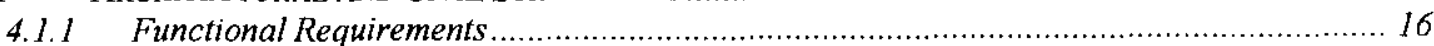

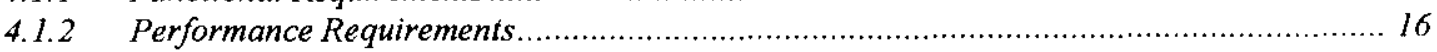

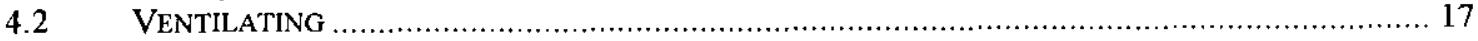

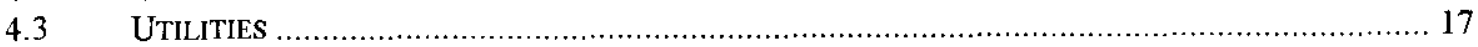

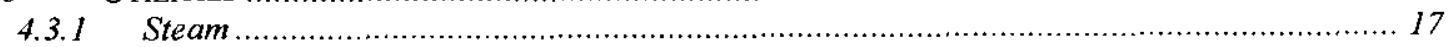

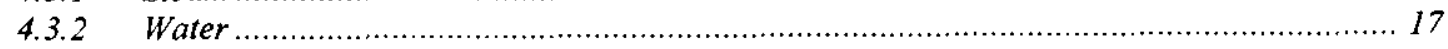

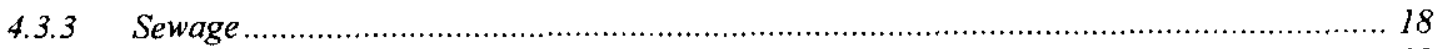

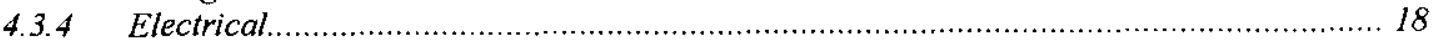

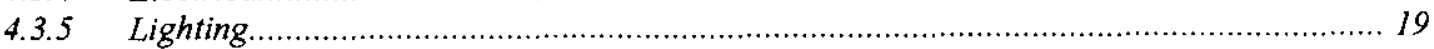

4.3.6 Air

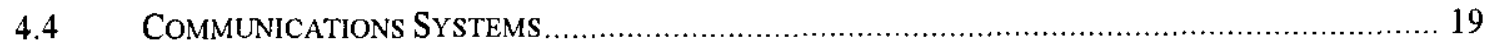

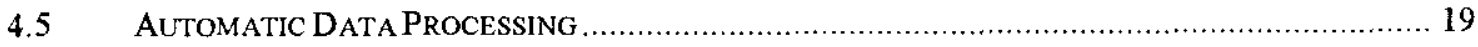

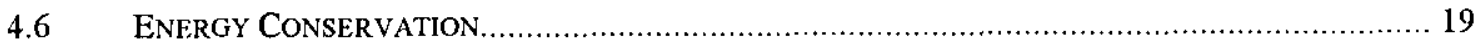

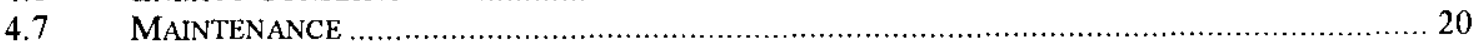

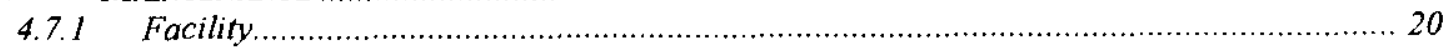

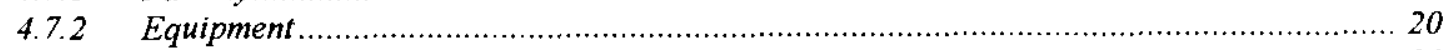

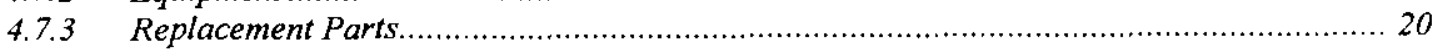

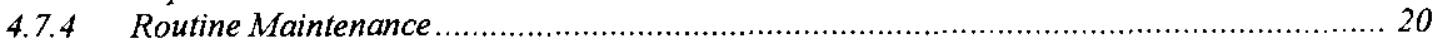

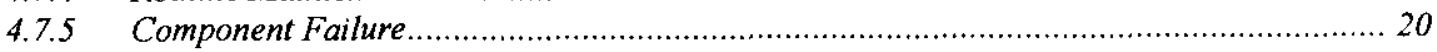

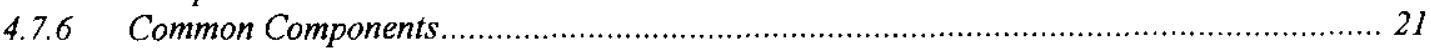

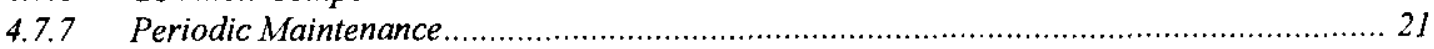

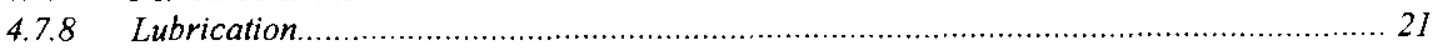


HNF-4412, Rev. 0

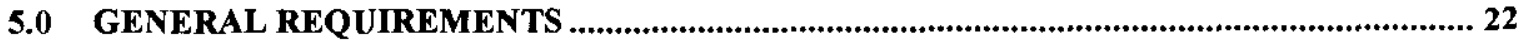

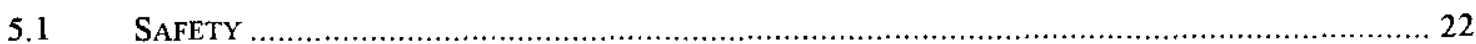

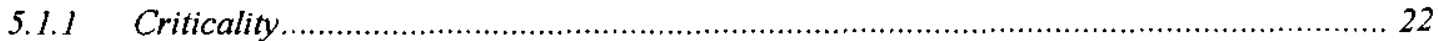

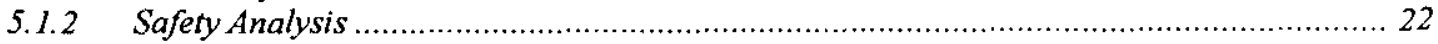

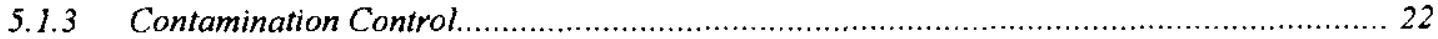

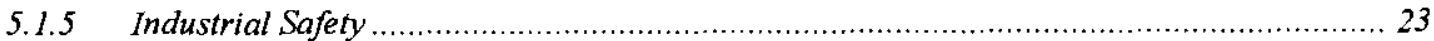

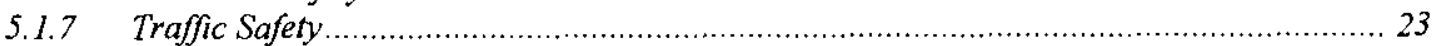

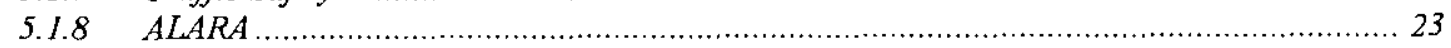

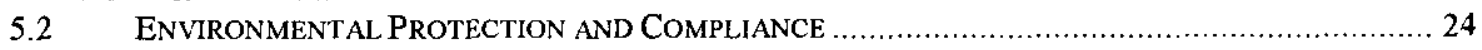

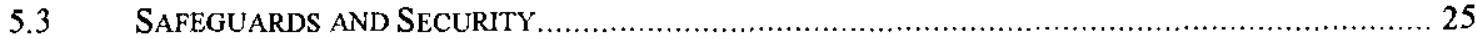

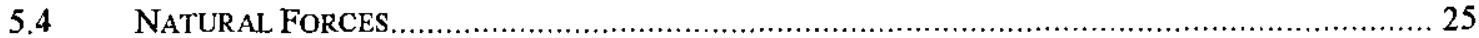

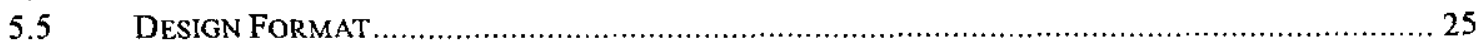

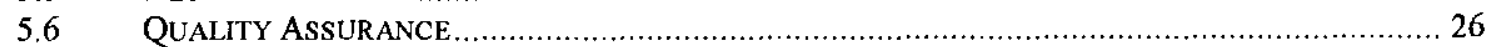

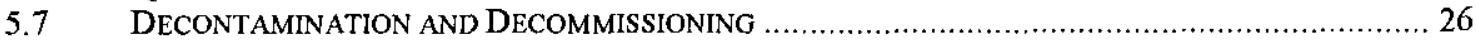

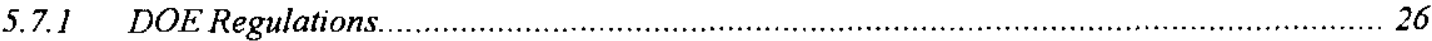

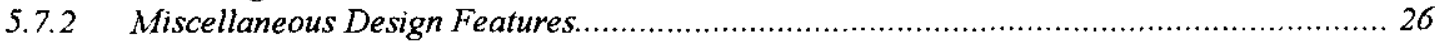

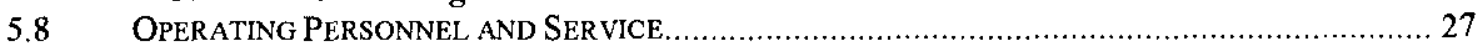

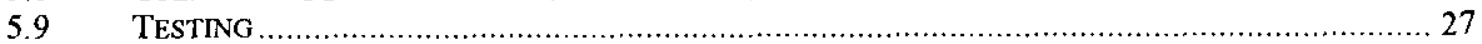

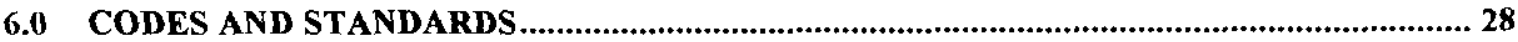

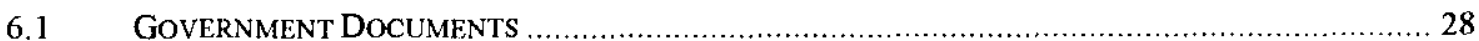

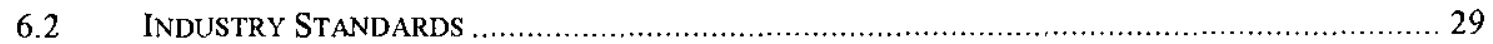

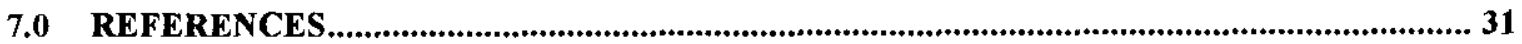

List of Tables and Figures

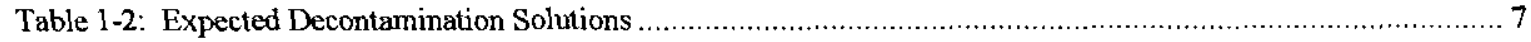

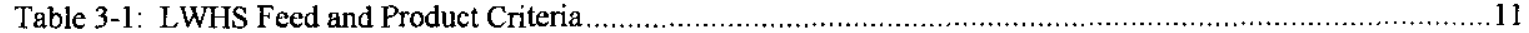

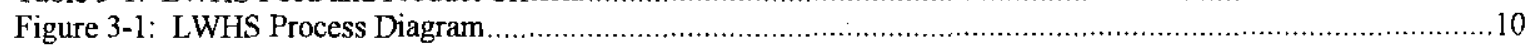




\section{Definitions}

ALARA

BWHC

CHA

$\mathrm{Ci}$

DOE

$\mathrm{ECN}$

EDL

FDH

FSP

Gy

HLV

Liquid waste

LLV

LWHS

LOS

REC

RLWS

Spent decontamination solution

SMF

TRU

User

WAC

WMP

WTEL
As Low As Reasonably Achievable

B\&W Hanford Company

cask handling area

Curie, $3.7 \times 10^{10}$ disintegrations per second

U.S. Department of Energy

Engineering Change Notice

Engineering Development Laboratory

Fluor Daniel Hanford, Inc.

Facility Stabilization Project

Gray, SI unit of radiative exposure, $100 \mathrm{Rad}$

High Level Vault

Liquid which has been processed by the LWHS

Low-Level Vault

Liquid Waste Handling System

Load Out Stall

Radiochemical Engineering Cells

Radioactive Liquid Waste System

Liquid produced from a sub project which is to be processed by the LWHS

Shielded Material Facility

transuranic

Sub project producing liquid to be processed by the LWHS

Washington Administrative Code

Waste Management Plan

Waste Technology Engineering Laboratory 


\section{Building Liquid Waste Handling System Functional Design Criteria}

\subsection{INTRODUCTION}

The 324 Building is located in the 300 Area of the Hanford Site, and until 1998 utilized the Radioactive Liquid Waste System (RLWS) which was operated by the 340 Waste Handling Facility. This system, now deactivated, allowed the transfer of radiological liquid waste through underground piping to 90-day storage tanks for transport to Tank Farms. Although the 324 Building no longer has a waste technology research mission, radiological liquid waste or spent decontamination solutions will be generated during deactivation and stabilization. Thus, a system for collection, transport, treatment and disposal of 324 Building spent decontamination solutions is necessary. This system, to be called the Liquid Waste Handling System (LWHS), requires the capability for liquid waste treatment to make the liquid acceptable for transport due to the expected high activity of the spent decontamination solutions. An engineering options study and conceptual design was prepared for B\&W Hanford Company (BWHC) by Parsons Infrastructure and Technology Group, Inc., in July 1998 (Ham 1998).

\subsection{Scope}

The purpose of this document is to define the functional design criteria for the 324 Building LWHS. The 324 Building LWHS will ${ }^{1}$ include the collection, treatment, holding and load-out of radiological liquid waste generated during deactivation and stabilization activities. It is anticipated that existing tanks, piping and equipment can be used to the greatest extent possible for the design of this system. All design activities shall conform to HNF-PRO-1819, PHMC Engineering Requirements.

\subsection{Background}

The 324 Building, known as the Waste Technology Engineering Laboratory (WTEL), is a former 300 Area Hanford Site laboratory constructed in the mid-1960s. The building is a nonreactor nuclear facility currently under transition from its mission of waste technology research to a deactivation and stabilization mission. The building contains office spaces, development laboratories, hot cells, vaults, tanks, galleries, pipeways, a trucklock, and a loadout station (or loadout stall). Some of the activities performed in the building were chemical and physical processing of radioactive materials, characterization of irradiated materials, and nonradioactive process development.

\footnotetext{
1 In this document, the term "will" is used to convey descriptive information, as opposed to functions and/or requirements. The terms "shall" and "must" are used to convey essential functions and/or requirements. The term "should" is reserved for highly desirable features that are strongly recommended, but not required.
} 


\subsubsection{Project Background}

The budget, scope, and schedule of this project are tracked and managed through current revisions of HNF-IP-1289, 324/327 Buildings Stabilization/Deactivation Project Management Plan (BWHC 1998), and a project file is being maintained by the project engineer.

Processing of the 324 Building spent decontamination solutions is required to ensure safe disposition of the radiological liquid wastes. Although actual concentrations of the spent decontamination liquid waste streams will not be known until generated, an upper bound estimation can be made for design purposes using process knowledge and facility documentation. Preliminary studies of facility decontamination approaches (Hendrickson 1999A), characterization strategy and data quality objectives (Hendrickson 1999B), LWHS treatment needs for transportation and disposal (Hendrickson 1999C), and dose assessment of spray leaks (Hoffman 1999) have been prepared.

Additional documents have also been generated to reflect changes in the treatment system location (Hafla 1999A), evaluate the re-use of the D-Cell treatment system (Hafla 1999B), document expected decontamination chemicals (Riddelle 1999), and establish liquid packaging and transportation limits (Peters 1999). The current assumptions used for this document are found in Section 1.5, Project Assumptions.

Stabilization of the 324 Building is anticipated to occur through both solid waste removal and liquid decontamination of radiologically-contaminated areas within the facility. First, large equipment and material waste will be size-reduced and packaged for disposal. Then, the remaining loose material will be collected and packaged for disposal. Finally, liquid decontamination will be employed to reduce contamination to allow the facility to meet closure and end-point criteria. Based on information contained in the 324 Building Closure Plan (DOE 1998), the spent decontamination solutions generated from areas within the closure boundary are expected to be dangerous waste.

The LWHS is required to remove up to $50 \mathrm{kCi}$ of activity from decontamination solutions generated during 324 deactivation activities. $24.6 \mathrm{kCi}$ of this number is based on an estimated $20 \%$ of the $123 \mathrm{kCi}$ B-Cell inventory (Greenborg 1999) remaining after physical clean-up activities are complete $(123 \mathrm{kCi}$ x $20 \%=24.6 \mathrm{kCi})$. The remaining $25.4 \mathrm{kCi}$ of activity is a conservative estimate for activity to be removed from the other radiological areas within the facility, including the radiochemical engineering cells (REC) and the high-level vault (HLV) and low-level vault (LLV) tanks. Specifically excluded from treatment at this time, are the inventories for the Shielded Material Facility (SMF) and the exhaust ducting. Expectations of radiological contamination in the decontamination solutions include ${ }^{137} \mathrm{Cs},{ }^{90} \mathrm{Sr},{ }^{154 / 155} \mathrm{Eu},{ }^{60} \mathrm{Co},{ }^{241} \mathrm{Am},{ }^{243 / 244} \mathrm{Cm},{ }^{238} \mathrm{Pu}$, ${ }^{239 / 240} \mathrm{Pu}$, and trace amounts of ${ }^{237} \mathrm{~Np}$ and $\mathrm{U}$.

Table 1-1 provides the volume projections of spent decontamination solutions (by facility area) that will be sent to the LWHS for treatment and disposal. The projected volume of facility liquid waste is estimated at $221,239 \mathrm{~L}$, or 58,452 gal (Ham 1998). This value may increase or decrease depending on the methods of decontamination employed. It is 
anticipated that liquid waste will be disposed at the tank farms with the LWHS design supporting transfer in the MC-312 package but allowing offloading capability to the LR56/H cask as an alternate method of transportation. Descriptions of these tankers may be found in the Safety Evaluation for Packaging MC-312 (Carlstrom 1996), and Safety Analysis Report for Packaging LR56/H (Smith 1998).

\begin{tabular}{|l|c|l|}
\hline Facility Area & $\begin{array}{c}\text { Anticipated Spent } \\
\text { Decontamination Solution }{ }^{1} \text { (L) }\end{array}$ & Facility Interface Points \\
\hline REC A-Cell & 12,491 & Pipe Trench \\
\hline REC B-Cell & 52,233 & Pipe Trench \\
\hline REC C-Cell & 8,743 & C-Cell \\
\hline REC D-Cell & 12,112 & Pipe Trench \\
\hline REC Airlock & 14,383 & Pipe Trench \\
\hline HLV & 41,525 & Pipe Trench \\
\hline LLV & 14,421 & Pipe Trench \\
\hline $\begin{array}{l}\text { Summary of REC } \text { and Vault } \\
\text { Tanks }\end{array}$ & 155,908 & \\
\hline Other potential sources ${ }^{2}$ & 65,331 & N/A \\
\hline $\begin{array}{l}\text { Summary of all Facility } \\
\text { Areas }\end{array}$ & 221,239 & \\
\hline
\end{tabular}

Notes:

(1) Volumes taken from HNF-3133, Rev. 0, 324 Building Liquid Waste Handling and Removal System Project Plan (Ham 1998).

(2) Not all solutions are anticipated to require treatment for liquid transport and disposal, and may require holding and load-out only.

\subsubsection{Building Background}

The 324 Building was designed to provide office and laboratory space for scientific and engineering staff who conduct multidisciplinary research in areas of waste characterization and immobilization, waste remediation and cleanup development, biomass research, spent fuel characterization, and cesium chloride encapsulation. Because the 324 Building housed research and development activities, the work being conducted changed as programs were concluded and other programs started. 
The 324 Building is divided into five, integrated but separate primary work areas: Engineering Development Laboratories (EDL) 101 and 102 (EDL-101 and EDL-102), the EDL-146, the REC, SMF, and manipulator repair shop (room 147). These facilities and adjunct facilities are described below.

Room 147 is in current use for the maintenance and repair of manipulators. The deactivation and decontamination of this room is not in the LWHS scope.

The EDL-101 and EDL-102 rooms have been used to perform bench-to-prototype scale engineering studies of waste immobilization processes with nonradioactive materials, depleted uranium, and thorium. EDL-101 was also used to develop sodium and lithium cleaning processes in support of development of the Fast Flux Test Facility.

The EDL-146 contained unshielded or mildly shielded fume hoods for studies with extremely toxic materials, tracer level fission products, and/or plutonium. Located next to EDL-146 is the sampling room (room 145), which contains sampling equipment for the HLV and LLV tanks.

The REC provided for studies of almost any type of chemical or mechanical process with radiation levels of up to $10^{4} \mathrm{~Gy} / \mathrm{hr}\left(10^{6} \mathrm{Rad} / \mathrm{hr}\right)$. The REC consists of four operating cells surrounding a common air lock cell. The airlock functions primarily as a transition zone and ventilation barrier for movement of shielded material between external areas and the four processing cells.

The REC A-Cell is a $10 \mathrm{~m}$-high cell that was most recently used for storage of vitrified waste in canisters. Thirty-four high-heat and high-radiation vitrified isotopic sources were temporarily stored in the cell. Ongoing operations are cleaning out this cell for temporary fuel and/or waste storage.

B-Cell is a 10 m-high cell that was used primarily to demonstrate several engineering scale prototypes of waste immobilization processes. B-Cell process equipment was designed and installed in rack configurations. The racks "plugged" into the cell walls through specially designed penetrations leading to the airlock. Split plugs allowed service connections to be made between the service galleries and the hot cells.

C- and D-Cells are shorter process cells, capable of handling equipment up to $3.35 \mathrm{~m}$ high, and are operated entirely by direct viewing and master-slave manipulators with assistance from remotely operated overhead cranes. Typical processes studied in these cells have been dissolution and separation of fuel element compounds by hightemperature gases or liquid salt melts, dejacketing of fuel elements, remote equipment development, and determination of physical properties of highly radioactive materials or equipment.

The SMF includes the south (fabrication), airlock, and east (feed preparation) cells. Complete containment of radioactive materials has been provided for remote research 
and fabrication studies on metallic and ceramic fuel materials with radiation levels on the order of $10^{4} \mathrm{~Gy} / \mathrm{hr}\left(10^{6} \mathrm{Rad} / \mathrm{hr}\right)$.

The cask handling area (CHA) is the central hub for control of radioactive material movements within the radiological areas of the building. This area is located east of the airlock and REC, northwest of the SMF cells, and west of EDL-146 and the manipulator repair shop (room 147). A trucklock provides for shipping and receiving. Material transfers between the functional areas are routed through the CHA. Facilities exist for load-in and load-out of large quantities of radioactive materials to any cell or to the shielded vault area through equipment in the trucklock and CHAs.

Two shielded vaults (HLV and LLV), containing stainless steel tanks ranging from 1,700 L to $18,500 \mathrm{~L}$, were provided for temporary segregation and holdup of radioactive liquid feed stocks for, or waste from, chemical processing and/or cleaning operations in the hot cells. Most of the liquid material transfer piping, connecting the various rooms, shielded vaults, and cells is contained within a pipeway beneath the REC airlock floor or embedded in the concrete structure (floors and walls).

The total floor area of these facility components is about $6,164 \mathrm{~m}^{2}$. Maximum overall building dimensions are: $62.5 \times 71.6 \times 13.7 \mathrm{~m}$ high. The radiation shielding of the hot cell walls is provided by the thick concrete ( $1.37 \mathrm{~m}$ normal density; $1.22 \mathrm{~m}$ high density).

Refer to DOE/RL-96-73, Rev. 1, 324 Building Radiochemical Engineering Cells, HighLevel Vault, Low-Level Vault, and Associated Areas Closure Plan (DOE 1998) and HNF-SD-SPJ-SAR-001, 324 Building Safety Analysis Report (BWHC 1997) for additional background information related to the 324 Building.

\subsection{Site Location}

The LWHS shall be housed within the existing 324 Building facility. Initial recommendations are to locate jumpers in the pipe trench and loadout station (LOS), pretreatment collection in the HLV, pretreated liquid sampling and treatment in C-Cell, post-treatment collection in the LLV, and transfer filtering and post-treatment sampling in the LOS. Offloading will be performed in the trucklock. Interference with other projects and 324 Building operations shall be minimized.

\subsection{Project Interfaces}

The LWHS design project requires interfacing with facility personnel representing operations, projects, waste management, radiological control, fire protection, safety, quality assurance, environmental, etc., to ensure a safe and operable system. Other interfaces will include Waste Management Hanford, Waste Management Federal Services Northwest Operations, and Office of River Protection. 


\subsection{Project Assumptions}

This section lists the assumptions used in the development of this document. This list is not meant to be all inclusive, but instead to provide the design agent with sufficient information to perform design activities, and to provide a means for facility concurrence of the proposed path for design.

It is assumed at this time that each user (or project) contributing spent decontamination solutions to the LWHS will be responsible for the arrangements of packaging, transport, and disposal of the solid and liquid waste recovered by the LWHS. However, an evaluation of the waste streams to be generated (e.g., transuranic [TRU], mixed, low level, etc.), and the requirements for packaging, transport, and disposal will be performed and documented in a Waste Management Plan (WMP). The WMP will include the proposed packaging, transport, and disposal paths for each anticipated waste stream.

Other assumptions:

- decontamination solutions will consist of those listed in Table 1-2

- decontamination solutions not listed in Table 1-2 must be accepted by the LWHS Project Manager prior to use (solutions must meet, or be capable of LWHS treatment to meet, transportation and disposal requirements)

- use of acids or bases as listed in Table 1-2 will be followed with an equal volume water flush

- transfer of spent decontamination solutions to the LWHS requires prior approval by the LWHS Project Manager (solutions must meet, or be capable of LWHS treatment to meet, transportation and disposal requirements)

- user will be responsible for pumps, filters and hoses outside of the LWHS boundary (see Table 1-1 and Figure 3-1)

- all users will be required to filter (<30 micron) spent decontamination solutions to prevent loading the HLV and LLV holding tanks with solids

- user will not mix incompatible spent decontamination solutions (e.g., acids and bases); separate holding tanks for these solutions will be identified by this design

- spent decontamination solutions will not exceed $32^{\circ} \mathrm{C}$

- to the greatest extent feasible, existing building features (e.g., cell walls, cover blocks, ventilation, etc.) will be used to maintain exposure to the workers, public and environment as low as reasonably achieveable (ALARA) during installation, operations, maintenance, and the removal of the treatment system.

- modifications to, or additions of safety class or safety significant equipment will not be required for this design

- all LWHS operations will occur within the 324 Building

- spent decontamination solutions will be treated to a level not to exceed Hazard Category 3 during load-out operations. 
HNF-4412, Rev, 0

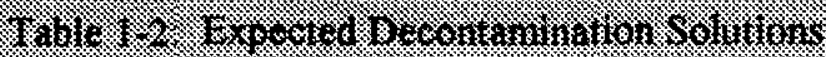

Expected Decontamination Solutions

Percent of Total Solutions Used

Chemical:

- 1.6 M Nitric Acid

- $0.25 \mathrm{M}$ Citric Acid

- $2.0 \mathrm{M}$ Sodium Hydroxide

$10 \%$

- $\mathrm{AP} /$ Citrox ( $\mathrm{AP}=2.5 \mathrm{M}$ Sodium Hydroxide/0.2 M Potassium Permanganate) (AP then $0.25 \mathrm{M}$ Citric/Oxalic)

- AP/Nitric Acid (AP then 1.6M Nitric)

Water:

- Medium/High/Ultra High ( 40,000 psi) Pressure $90 \%$ Wash of carbon/stainless steel, and painted concrete surfaces. 
HNF-4412, Rev. 0

\subsection{PROJECT CRITERIA}

The LWHS shall provide for a system to collect, treat, store, and remove spent decontamination solutions generated from 324 Building deactivation. This system shall provide equipment and/or methods for:

- transfers from defined facility interface points to pretreatment collection

- $\quad$ liquid transfer to and from LWHS treatment units and the existing holding tanks within the HLV and LLV

- treatment of spent decontamination solution for contaminants (both radioactive and nonradioactive) as necessary for transportation and disposal

- $\quad$ sampling of LWHS feed and treated effluent

- $\quad$ handling and drying of recovered solids

- $\quad$ truck loading capability for liquid waste disposal.

All treatment equipment (e.g., filters, ion exchange modules) shall be located within the existing structure of the 324 Building and the closure boundary (DOE 1998)

\section{$2.1 \quad$ Functional Requirements}

The design shall implement the U.S. Department of Energy (DOE) requirements for radioactive waste handling and disposal and Washington state requirements for dangerous waste handling. The system provided shall minimize the impact on 324 Building material removal operations and liquid decontamination by minimizing service interruptions during construction, testing, and operation of the project. The project shall meet the appropriate sections of DOE Order 6430.1A, General Design Criteria, and applicable Project Hanford Management Contract, Facility Stabilization Project (FSP), and 324 Building specific procedures.

\subsection{Performance Requirements}

- $\quad$ design life for the LWHS shall be a minimum of ten years

- LWHS shall provide surge capacity for decontamination solutions using existing tank capacity

- LWHS equipment shall have a minimum availability factor of $50 \%$ (i.e., $24 \mathrm{hr} /$ day, 182 day/yr)

- $\quad$ LWHS shall be capable of processing 15,140 L (4,000 gal) in one week

- truck loadout equipment shall have a minimum availability factor of $50 \%$ (i.e., $24 \mathrm{hr} /$ day, 182 day/yr)

- $\quad$ truck loadout equipment shall enable loadout to both LR56/H and MC-312 configuration transport packages

- $\quad$ truck loadout equipment shall be capable of loading 15,140 L (4,000 gal) of liquid waste within 8-12 hours

- LWHS equipment shall be capable of being installed within the capabilities of existing facility equipment. 


\subsection{PROCESS CRITERIA}

Commercially available equipment shall be selected, where available. Equipment requiring special handling features should be avoided. All systems shall be configured to be fail-safe upon power loss and to minimize personnel radiation exposure during recovery.

\subsection{General Process}

The deactivation and stabilization of the 324 Building will require significant removal of contaminated equipment and other material. Following the removal of this material, additional decontamination of the building interior structure (e.g., walls, ceilings, floors) and piping is required to meet stabilization goals (DOE 1988). The additional decontamination methods expected will generate significant volumes of spent decontamination solution. Complete stabilization of the facility cannot occur without removal of these liquids from the building. Treatment of the spent decontamination solution for radioactive and nonradioactive contaminants is required to allow shipment and disposal of the liquid waste.

The spent decontamination solution from facility areas (e.g., cells, airlocks) will be transferred by the users to tank holding within the REC, HLV, or LLV and accumulated for processing. The accumulated spent decontamination solution will be processed by the LWHS and returned to holding. Sampling and analysis of both the liquid feed input and the treated output will provide waste verification for transport and disposal. The treated effluent will be offloaded to a tanker truck for transportation to an appropriate disposal unit. It is anticipated that spent decontamination solution will be received from no more than one facility component at a time, but that waste streams may be aggregated, where compatible, for treatment. Figure 3-1 provides an anticipated process diagram.

\subsubsection{Functional Requirements}

LWHS Treatment Operations shall:

- be designed to receive spent decontamination solutions and produce treated liquid waste as described in Table 3-1

- $\quad$ provide destruction method (e.g., wet oxidation) for organic decontamination agents such as Citrox

- $\quad$ provide $\mathrm{pH}$ control capability for various inputs, as necessary

- $\quad$ provide filtration to remove precipitated TRU constituents prior to ion exchange treatment (i.e., prevent ion exchange media from being classified as a TRU waste)

- $\quad$ provide capability to remove dissolved radionuclides from the spent decontamination solutions

- $\quad$ provide ability to segregate and/or process small quantities of grease and oils.

- provide spare "plug in" at the front of the treatment system for a future component 


\section{Figure 3-1: LWHS Process Diagram}

(1) Influent Stream (expected)

**See values in Table 3-1**

(2) Effluent Stream Requirements

**See values in Table 3-1**
Decon Areas

(REC Cells,

HLV, LLV,

Airlock, etc)
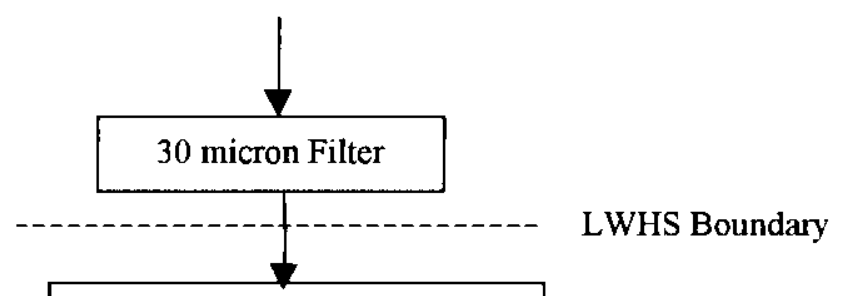

Pre-Treatment Holding Tank(s) 400-5000 gal

(1)

\section{Treatment Skid}

Destruction of: Separation of:

- Organics (wet oxidation) - Heavy metals

- TRU

- Strontium

Drying of: - - Cesium

- Filters/Columns

Liquid

(2)

Solid

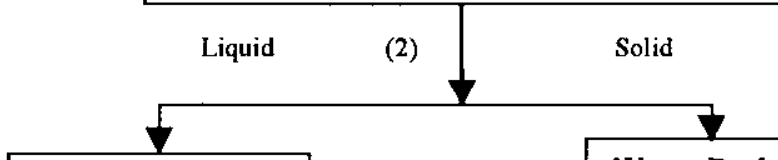

Post-Treatment

Holding Tank(s)

$3000-4800 \mathrm{gal}$

aste Packaging

- Columns

- Filters

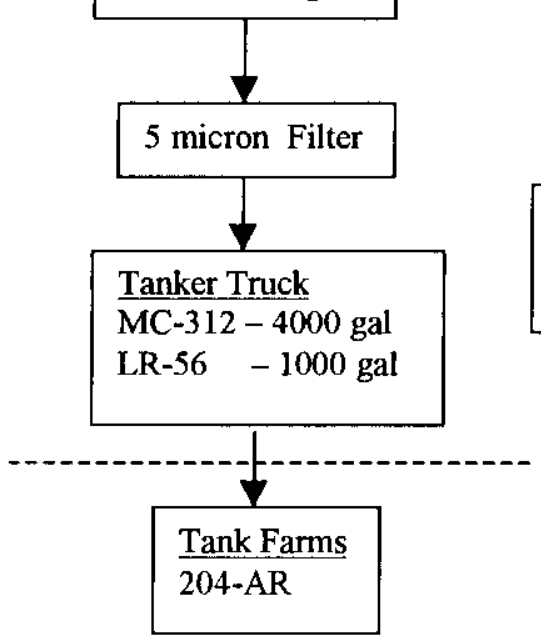

LWHS Boundary

\section{LWHS Boundary}


- $\quad$ provide flush, drain, and decontamination arrangements for treatment system internals

- $\quad$ provide rework capability for post treatment liquid waste in case transportation or disposal requirements are not met

- $\quad$ provide unit operations by-pass capability for entire skid and individual units.

LWHS Offloading shall:

- $\quad$ provide the capability to load liquid wastes into tank trucks of configurations equivalent to the MC-312 or LR-56 to capacity in 8-12 hours

- $\quad$ provide $5 \mu \mathrm{m}$ solids filtration for liquid waste transfers from holding to LWHS offloading to inhibit settling of solids in transportation

- $\quad$ provide MC-312 or LR-56 liquid level monitoring and alarm capability for use during loading

- $\quad$ provide the capability to flush and drain the transfer line after use

- $\quad$ provide controlled release of minor leaks and spills by providing secondary containment in the trucklock.

\subsection{Instrumentation and Control}

\subsubsection{Functional Requirements}

Instrumentation shall be provided for:

- liquid level and specific gravity for holding tanks, surge tanks, reagent tanks, the MC-312, and LR-56 tanker truck, as necessary for operation

- flowrate and volumetric totalizing of processed volumes

- input to low, high and very high level alarms for holding tanks, surge tanks, reagent tanks, the MC-312, and LR-56 tanker truck, as necessary for safe operation

- differential pressure across each process module, as needed

- gamma energy detection for ion exchange effluent lines

- monitoring of major treatment parameters as required.

- leak detection, as required.

\subsubsection{Performance Requirements}

Instrumentation applied in the operation of the LWHS should be minimized and shall provide:

- effluent gamma monitoring with a detection limit basis not exceeding 1 micro-curie per liter of ${ }^{137} \mathrm{Cs}$ and a range encompassing the expected values

- electronic and/or hard copy data storage of LWHS performance parameters, including treatment volume, tank levels, level alarms, differential pressures across flow modules, and effluent gamma monitoring. 


\subsubsection{Computer-Based Process Controls}

Computer-based process controls are not required, only data logging is required. However, exclusion of computer-based process controls is not intended. The LWHS operations are intended to be conducted under continuous attendance but with limited (start/stop/ instrumental observation) requirement from an operator. The primary indication of treatment effectiveness will be gamma measurement of the effluent. Alarm setpoints for the operator shall be established to allow process shutdown or recycling of effluent to the feed tank dependent upon breakthrough or level alarm. Instrumentation shall be maintained in calibration (gamma detector may have internal computer-based standard).

\subsection{Piping and Vessels}

The ASME, Boiler and Pressure Vessel Code, Section III, Class II or other comparable safety-related codes and standards that are appropriate for the system being designed is required for all new facility safety-class construction in accordance with DOE 6430.1A. For nonsafety class applications, new or modified piping shall comply with ASME B31.3 Process Piping standards. Piping and vessels employed shall be compatible with waste streams described in Figure 3-1 and Table 3-1.

\subsubsection{Functional Requirements}

Piping shall:

- $\quad$ assure safe transfer of spent decontamination solutions from the facility interface point to holding tanks.

- $\quad$ assure safe transfer from holding tanks to treatment unit

- $\quad$ assure safe transfer from treatment unit to holding tanks

- $\quad$ assure safe transfer from holding tanks to offloading unit

- $\quad$ safely transfer chemical reagents being introduced to the LWHS

- be supported appropriate to vibration, mass, and seismic considerations

- $\quad$ be designed with the capability to conduct pressure tests for integrity assessment

- provide the ability to recycle the treated liquid waste to spent decontamination solution holding

- $\quad$ have backup isolation valving and bypass capability for major components

Holding vessels shall:

- $\quad$ assure safe receipt and holding of spent decontamination solutions and liquid waste (typically through liquid level measurement)

- provide mixing capability to minimize heels and obtain representative sampling, in new tanks as necessary

- $\quad$ provide sufficient holding capacity for process feeds consistent with spent decontamination solution generation, treatment rate, and liquid waste offloading

- provide sufficient holding capacity for treated liquids consistent with sampling, analysis, and transportation considerations

- $\quad$ provide transfer capability to the waste treatment unit from the holding tanks 


\subsubsection{Performance Requirements}

Piping shall:

- be labeled in accordance with ASME 13.1 Scheme for the Identification of Piping Systems, and HNF-IP-1264, Section 7.1, as appropriate

- $\quad$ be designed to ASME Boiler and Pressure Vessel Code, Section III, or comparable criteria if a safety-class item

- be designed to ASME Process Piping Code (ASME B31.3) if not a safety-class item

- $\quad$ be compatible with decontamination solutions specified in Table 1-2, and radiological constituents specified in Table 3-1

- be vented at high points if necessary to avoid siphoning and overfilling of vessels or processes

- allow flushing and drain back to holding vessels to maintain personnel dose protection ALARA

- $\quad$ be designed with large radius bends (enhancing solids entrainment)

- be designed to provide transfers with linear velocities sufficient to prevent solids accumulation, or provide flushing for existing lines

Vessels shall:

- be compatible with spent decontamination solutions and reagents anticipated to be used during the operational life and decommissioning of the LWHS.

- $\quad$ provide segregated holding of acidic and basic spent decontamination solutions to minimize solids accumulation within the holding vessels due to precipitation, or provide option to combine solutions in a neutralization tank at the treatment skid

- $\quad$ provide sufficient heat removal capability, if required, for potential exothermic reactions in the LWHS treatment system preventing temperature rises from significantly affecting downstream treatment operations or transportation vessel limits $\left(82^{\circ} \mathrm{C}\right.$ for $\mathrm{LR} 56 / \mathrm{H}, 52^{\circ} \mathrm{C}$ for $\left.\mathrm{MC}-312\right)$.

\subsection{General Mechanical Processes}

\subsubsection{Functional Requirements}

General mechanical processes considered within the LWHS include pumping, filtration, and liquid sampling. To the extent that these activities must be conducted in radiological environments, the design of these processes (and their maintenance) shall:

- consider performance, service life, seismic requirements, and reliability goals

- $\quad$ minimize special handling features to prevent damage during installation

- use commercially available equipment and parts to the greatest extent practical; reliability and interchangeability shall be part of all specifications and design requirements 
- locate complex components, or those having a high rate of failure under high radiological conditions, outside of remote cells when practical

- $\quad$ Provide maintenance (if available) and operation documentation for all equipment

- be designed for easily replaced components in remote locations (e.g., cells, pipe trench, LOS)

- be designed for recovery from in-process failures using remote equipment (i.e. capable of being repaired/replaced by cranes and manipulators).

\subsubsection{Performance Requirements}

General mechanical processes shall:

- $\quad$ provide fail-safe shutdown in the event of loss of system supply power

- be compatible with potential and actual presence of corrosive decontamination solutions, including acids, strong detergents, and nitric acid fumes or spills

- $\quad$ prevent a single failure of mechanical or electrical equipment from causing a loss of control that will result in an unrecoverable condition. 


\subsection{FACILITY CRITERIA}

\subsection{Architectural and Civil/Structural}

\subsubsection{Functional Requirements}

Modifications for the new loadout station shall:

- be designed in accordance with HNF-PRO-097, Engineering Design and Evaluation.

- include a leak collection system (e.g., portable secondary containment and any spills will be wiped up or otherwise absorbed)

- $\quad$ include space considerations for a step-off pad and provisions for changing personnel protective clothing and equipment if required

- $\quad$ include level monitoring capability for the tanker being loaded

- be compatible with the MC-312 tanker used at 204-AR

- not consist of permanent fixed structures (consists of removable hoses and portable stairs with handrails to allow access to the MC-312).

An adapter and the ability to load the LR56/H should be considered and provided.

The site selected for the treatment skid shall accommodate installation, the removal and servicing of LWHS treatment equipment, and decommissioning activities.

Access control for high and very high radiation areas shall comply with HSRCM-1.

New equipment installations shall be designed or include provisions to minimize worker exposures to internal and external radiological and chemical hazards. To minimize personnel exposures, supplemental shielding and other radiation protection measures will be provided as required.

Design features shall confine contamination within the REC, HLV, LLV, LOS, tanker truck, and hoses/piping within the truck lock, and minimize the spread of contamination.

\subsubsection{Performance Requirements}

All installations will be inside the existing 324 structure and will not be directly exposed to the weather. Piping and electrical conduit trays/racks shall be routed to accommodate access for installation and component removal (e.g., ion exchange module), or other maintenance related items.

Spill control and retention shall be provided for all systems/components by existing facility structures. Some modifications may be required to provide recovery back to the LWHS (e.g., ability to connect temporary steam line to HLV and LLV jet gang valves for sump jets). No new concrete structures should be required; however, any new concrete used with 


\section{HNF-4412, Rev. 0}

the potential of becoming contaminated shall be sealed with a material that is smooth and essentially impermeable to radioactive material. (DOE Order 6430.1A, 1323-5.3).

\subsection{Ventilating}

The LWHS design shall stay within all building ventilation system limitations. All spent decontamination solution streams and the holding, transfer, and treatment equipment for these streams shall be located in areas ventilated to provide double HEPA filtration (Zone 1) for this design. Any contaminated or potentially contaminated air exhausted from the offloading station or trucklock shall be HEPA-filtered or exhausted back to the LOS or other 324 Building direct Zone 1 ventilation space (H-3-20389).

\subsection{Utilities}

Present utilities to and within the 324 Building include $621 \mathrm{kPa}$ (90 psi) steam (some process uses are currently blanked), compressed air, potable and process water, sanitary water, and up to $480 \mathrm{~V} /$ three-phase electrical supply.

Additional utilities that are required to service new/modified waste treatment equipment shall be provided by the facility. However, all utility interfaces with the LWHS are considered a part of this project. The electrical wiring runs should be designed with spares appropriate to the system design and life cycle.

\subsubsection{Steam}

If required for the LWHS, its operation, or decontamination, steam shall be provided by the facility. Saturated steam at $621 \mathrm{kPa}(90 \mathrm{psi})$ is currently available within the 324 Building as generated by a package boiler and may be provided for LWHS support. New or modified steam lines may be required to support holding in the HLV and LLV. Methods and supplies for a temporary connection of steam to the HLV and LLV sump jets may be required to recover liquids from secondary containment. The use of steam jets for transfers shall be used only if other methods are not practical. Although some transfers within the projects for stabilization and decontamination of the 324 Building components may be conducted with steam jets, the LWHS internal and external transfers are expected to be gravity or pump-operated.

\subsubsection{Water}

Process water will be required to support the LWHS in conducting neutralization agent preparation, LWHS flushing, and line flushing. The boundary for supply of process water shall be at the LWHS treatment system enclosure outside boundary. Process water shall be available upon demand in quantities not exceeding 5,700 L/day (1,500 gal/day). Process water shall be delivered at pressures not less than $345 \mathrm{kPa}(50 \mathrm{psi})$ and at temperatures between $10^{\circ} \mathrm{C}$ and $35^{\circ} \mathrm{C}$. 
Freeze protection is not required. All installations and modifications shall be within the 324 Building and shall be protected by the existing facility heating, ventilation, and air conditioning. Sanitary water will not be provided by this project.

\subsubsection{Sewage}

Not applicable. The LWHS will not interface with the sanitary water system. Product solutions will not be transferred to the process sewer. Existing sewage utilities are presently deemed to be adequate for facility personnel. LWHS process liquid wastes shall be removed from the facility by transport vessel to appropriate disposal.

\subsubsection{Electrical}

Electrical equipment, installations, and modifications shall be designed to meet applicable requirements of HNF-PRO-088, Electrical Work Safety, and HNF-PRO-089, Electrical Installation Safety.

480 VAC three-phase power and 240/120 VAC single-phase power are available for use at the treatment skid and as necessary for major powered equipment, instrumentation, and alarm systems. All electrical components, instrumentation, and their insulation shall be compatible with expected environmental and radiological conditions, and shall be located in accessible locations as much as practical.

Electrical power required for the LWHS treatment system shall be provided by existing Motor Control Centers (MCC) or power panels (e.g., the existing D-Cell MCC). The LWHS Project shall provide the equipment necessary to interface with the supplied power, including required $\mathrm{MCC}$ modifications.

\subsubsection{Functional Requirements}

Electrical capacity shall be provided to handle average and peak loads. To facilitate potential future modification, oversize capacity should be considered. Ground-fault circuit interrupter protected outlets shall be provided in potentially wet or damp locations if any new installations are required for the system.

\subsubsection{Performance Requirements}

New or modified electrical systems shall comply with NFPA 70, The National Electrical Code, and applicable sections of DOE Order 6430.1A. All control panels shall conform to UL 508. Electrical equipment shall be suitable for their intended use, maintenance, and installation. Equipment and materials installed by this project shall not contain mercury or polychlorinated biphenyls.

All safety switches and circuit breakers shall be equipped with provisions for locking out. All electrical equipment shall be in watertight enclosures and electromagnetic transmission shall not be used within the LWHS treatment equipment. Conduit fill shall comply with NFPA 70. 
Emergency electrical power supply for operation is not required. Fail-safe operations of this system require active processing and flows to terminate in order to mitigate against environmental release in the event of facility power loss.

Grounding of powered equipment and liquid transfer systems, particularly within the loadout subsystem, shall be incorporated in accordance with NEC and IEEE Recommended Practices for Grounding Industrial and Commercial Power Systems. Sensitive electronic instruments should not be placed within the confines of the LWHS treatment unit without analog backup.

\subsubsection{Lighting}

Existing facility lighting is sufficient and new lighting will not be required.

\subsubsection{Air}

Compressed air shall be provided by the process air supply. Air quantity and quality requirements shall be considered.

\subsection{Communications Systems}

Present communication systems within the facility are sufficient and include telephone, public address, computer local area network, and hand-operated radio systems. Alarm systems present within the facility include criticality, continuous air monitor, area radiation monitor, and fire.

Instrument signal collection shall be provided in the monitoring and control area (C-Cell gallery).

\subsection{Automatic Data Processing}

Automatic Data Processing requirements will be defined during the design process but are deemed to be primarily constrained to instrumental data acquisition and archival.

\subsection{Energy Conservation}

General design guidelines for energy conservation are in DOE 6430.1A, Sections 0110-12, 1595-10, and 1595-11. These guidelines apply to design and construction of new facilities and redesign or retrofit of existing facilities, both process and nonprocess. Facilities that meet the applicability criteria of 10 CFR 435 must also comply with DOE 6430.1A. Additional policies and requirements are in DOE 4330.2C. These guidelines and requirements should be considered but may not be applicable to the intermittent operational basis of this project. 


\subsection{Maintenance}

The design and material selection shall include features that facilitate maintenance of the equipment and the facility. Particular attention shall be paid to pumps, valves, and any equipment in high or very high radiation areas. Components requiring frequent change-out or maintenance shall be located in a more readily accessible location if possible rather than high contamination and/or high radiation areas.

Maintenance shall be conducted using remote handled items in high radiation areas (e.g., manipulators, crane). Components with radiation sensitive parts should be located in low dose areas or shielded appropriately. Accumulated component dose shall be considered during design. Materials considered essential for repair outside of these process areas must be sufficiently decontaminated prior to removal from the high radiation area. The history of crane failures and difficulty in repairs shall be considered during design.

\subsubsection{Facility}

The trucklock offloading modification shall be designed to function for a minimum of ten years.

\subsubsection{Equipment}

The LWHS shall be designed to facilitate safe cleanup. Consideration should be given to in-place or in-service repair and preventive maintenance of equipment to minimize cost of disassembly and interruption of service. The equipment shall be designed to be operated and maintained in a high radiation area and operated under contaminated conditions.

\subsubsection{Replacement Parts}

The equipment shall be designed to use standard replacement parts to the extent possible. Any parts, materials, or assemblies expected to degrade or wear during normal use or exposure shall be easily replaceable.

\subsubsection{Routine Maintenance}

The design shall minimize the need for special tools required to perform routine maintenance. The design shall consider manipulator based-maintenance for remote operation, processing, and component replacement.

\subsubsection{Component Failure}

The failure of any system component shall not reduce the design life, diminish the maintainability, nor compromise or reduce the capabilities of the LWHS or any associated interface components. Components that may fail or wear out before the end of the projected life shall be identified on a spares list with recommended stock and inventory included. 


\subsubsection{Common Components}

To the maximum extent practicable, common components shall be used to minimize spare parts, tools, and procedures.

\subsubsection{Periodic Maintenance}

Periodic maintenance capabilities shall be included in the design to prolong the effective lifetime at a minimum cost and downtime.

\subsubsection{Lubrication}

Components shall be designed to be permanently lubricated to the maximum extent possible. If lubrication is required, the equipment shall be designed to allow lubrication through the use of fittings and without requiring the disassembly of any parts other than the simple removal of protective caps or booting. The leakage of lubricants into the process effluent shall be minimized. The impact of leakage of any required lubricant shall be included in the design and performance of the LWHS. The presence and use of lubricants shall be identified by type and quantity for incorporation into the facility's fire hazard analysis. 


\subsection{GENERAL REQUIREMENTS}

\subsection{Safety}

\subsubsection{Criticality}

The design shall evaluate and if required include provisions to prevent criticality. The preference for criticality prevention is as follows:

- $\quad$ maintain a safe geometry

- limit mass accumulation

- apply administrative controls.

It is not anticipated that design features will be required for the LWHS system but criticality shall be addressed in the design process. It is expected that the current small quantities of fissionable materials will be removed by other means prior to liquid decontamination, such that the remaining quantities of these materials will be well below levels requiring special criticality design features in the LWHS.

\subsubsection{Safety Analysis}

The safety classification of systems, components, and structures shall be determined and applied to this project in accordance with HNF-PRO-704, Hazard and Accident Analysis Process. It is expected no safety class components will be required. Some components may be safety significant (hydrogen concentration control and effluent monitoring and control), but the majority are expected to be general services. An evaluation of HNF-SD-SPJ-SAR-001, 324 Building Safety Analysis Report shall be made, and any new requirements documented in an Engineering Change Notice (ECN) for incorporation into the SAR.

\subsubsection{Contamination Control}

Guidance provided in HSRCM-1, Hanford Site Radiological Control, and DOE Order 6430.1A shall be considered. Particular aspects of consideration within DOE Order 6430.1A shall include sections 0110-9, 0110-99.0.1, 0275-99.0.2, 1161, 1300-7, $1300-11.1,1323,1324-6.1,1324-7.2$, and 1325-4.

Where not maintained within permanent confinements or containments, the LWHS shall be designed and arranged to accommodate temporary confinements and/or containments (e.g., greenhouses, glovebags, catchbags, etc.) to facilitate maintenance work, lower the risk of exposure to workers, and to minimize the spread of contamination. 
Shielding

Shielding provided by existing structures should be sufficient. If required, shielding of the LWHS shall be provided to reduce worker exposure in support of ALARA principles. Shielding may be fixed or movable. Radiological engineering calculations to define specific shielding needs shall be made during the design process. Guidance provided in HNF-PRO-1621, ALARA Decision Making Methods shall be considered.

\subsubsection{Industrial Safety}

All activities performed on site shall meet applicable requirements of HNF-IP-1264, 324 Facility Stabilization Project Administration Mamual (Seay 1997), HNF-IP-1277, 300 Area Radiological Control Procedures, and shall utilize HNF-MP-003, Project Management Hanford Contract Integrated Environmental, Safety and Health Management System (ISMS) (Jackson 1997).

Some construction and waste packaging activities may require workers to be in close proximity to radiological contamination. All controls warranted to afford protection from potential radiological releases shall be implemented. Facility procedures will be implemented to ensure the safety of the construction and operating personnel in and around the area of the existing 324 Building. An eyewash station/safety shower shall be provided in the truck loadout station. State and federal safety and health shall be used and enforced during all construction phases of this project.

Fire Protection

Fire protection requirements for the 324 Building LWHS are defined by Letter, BWHC-B324-101, Rev 0, Revised Combustible Limits in REC A \& C Cells, Building 324, M.H. Chew \& Associates, Inc, dated 5/25/99, and HNF-SD-HT-FHA-002, 324 Facility Fire Hazards Analysis (Gregonis 1997). Letter, BWHC-B324-101, identifies the basis for a $100 \mathrm{Kg}$ (plastic equivalent) combustible loading limit. Any changes to this limit shall be documented in an ECN and then incorporated into the most current revision of the FHA.

\subsubsection{Traffic Safety}

Loading of trucks with liquid and packaged waste will occur only within the trucklock. Traffic safety will be addressed by the Facility via administrative controls and existing equipment. Additional highway controls will be met through appropriate road closures to the public and packaging authorization and approvals.

\subsubsection{ALARA}

The applicable requirements of the following documents shall be met:

- $\quad 10$ CFR 835, Occupational Radiation

- HSRCM-1, Hanford Site Radiological Control Manual

- $\quad$ DOE 6430.1A, General Design Criteria

- HNF-PRO-1621, ALARA Decision Making Methods 
- HNF-PRO-1622, Radiological Design Review Process

- HNF-PRO-1623, Radiological Work Planning Process

- HNF-PRO-1633, ALARA Program Records

- DOE-5400.5, Radiation Protection for the Public and the Environment

- $\quad$ DOE 5820.2A, Radioactive Waste Management

In particular, the requirements of 10 CFR 835, Subpart K, "Design and Control," shall be satisfied. The design objective for external exposure for the LWHS shall be that no individual worker shall receive an annual dose equivalent in excess of $500 \mathrm{mrem} / \mathrm{year}$ from all sources.

All (design agent) actions and decisions taken to maintain occupational exposures ALARA shall be documented [10 CFR 835.704(b)]. These records shall be retained until final disposition is authorized by DOE [10 CFR 835.701(b)].

Area radiation monitors shall be provided as necessary. To ensure compatible systems are used for all 300 Area Stabilization projects, equipment selection shall be approved by the facility Radiological Controls organization. Design, procurement, and delivery of all materials containing radioactive sources shall also be coordinated with the facility's Radiological Control organization.

\subsection{Environmental Protection and Compliance}

The acquisition of environmental permits and conformance to those permits shall be the responsibility of Fluor Daniel Hanford, Inc. (FDH). A preliminary analysis of environmental requirements (Weiner 1998) indicates that environmental issues for the 324 LWHS include:

- $\quad$ compliance with the National Environmental Policy Act

- $\quad$ compliance with the Washington State Environmental Policy Act

- compliance with the 324 Building Closure Plan

- $\quad$ compliance with the Clean Air Act

- completion and submittal of applicable federal, state, and local permit applications

- development of suitable on-site and off-site transportation requirements and strategy

- incorporation of suitable interface controls and agreements with Tank Farms, 200 Area, and 300 Area liquid effluent facilities to allow transfer of liquid waste.

Liquid wastes generated will be sampled, characterized, designated, and transferred to an appropriate receiving facility (e.g., Tank Farms). Solid wastes generated, including spent equipment, tools, filters, and ion exchange columns, will be packaged and dispositioned appropriately. All such wastes are expected to be radiologically contaminated and some may contain hazardous waste constituents as defined per Washington Administrative Code [WAC] 173-303. Waste Management Technical Services, will develop a Waste Management Plan to address the disposition of these wastes streams. 
The LWHS is expected to include treatment methods such as wet oxidation, neutralization or $\mathrm{pH}$ adjustment, precipitation, filtration, and ion exchange or sorption. Regulatory requirements for these unit operations are being addressed in a modification to the 324 Building Closure Plan (DOE 1998).

\subsection{Safeguards and Security}

A vulnerability assessment will be performed to determine safeguards and security requirements. The vulnerability assessment will, at a minimum, address the requirements of HNF-PRO-427, Site Safeguards and Security Program Planning Requirements.

\section{$5.4 \quad$ Natural Forces}

The anchorage of structures, systems, and components shall be in accordance with HNF-PRO-097, Engineering Design and Evaluation. Modifications to the LOS shall be evaluated for appropriate seismic adequacy according to General Service requirements.

Appropriate measures should be taken to deal with periodic increases in the local atmospheric particulate matter loading typical of a desert climate (i.e., wind-blown sand and dust). All enclosed vessels shall be weather-protected as required.

\subsection{Design Format}

Drawings shall be prepared in accordance with HNF-PRO-709, Preparation and Control Standards For Engineering Drawings, FSP-242, Engineering Drawing Requirements, and FSP-444, Vendor Information Requirements.

Sufficient vendor documentation, including but not limited to component description, operating, maintenance, and installation instructions, shall be provided to support safe operation, maintenance, and to document compliance with applicable codes, design standards, regulations, and environmental conditions. Essential facility drawings, as determined by the facility, shall be modified to show LWHS interfaces. In addition to construction drawings, instrument, electrical, and flow diagrams shall be prepared and will be considered essential drawings to support the safe operation and maintenance of the system. All design drawings created or changes made shall be field verified by FDH.

\subsection{Quality Assurance}

All contractors involved in the design, procurement, fabrication, or construction of the safety-related portions of the LWHS shall have a documented, FDH approved, Quality Assurance (QA) program meeting the applicable requirements of HNF-MP-599, Revision 3, Project Hanford Quality Assurance Program Description, Part 2, Sections 1-10, Subsections 3. This citation provides the Hanford Site implementation document for 10 CFR 830.120, Quality Assurance. Implementation of these requirements shall provide the following assurances: 
- $\quad$ design data and design decisions are documented, verified, and traceable

- design and design criteria are adequately supported by the prepared plans, specifications, and analyses

- design meets the baseline design criteria

- $\quad$ procured items and services meet applicable design requirements

- construction is performed in accordance with the definitive design documents

- testing and inspection confirms the adequacy of design, the quality of the construction and manufactured components, operability and maintainability, and reliability.

\subsection{Decontamination and Dispositioning}

All equipment and/or facilities provided by this project shall be designed and constructed to facilitate periodic decontamination, as well as final dispositioning.

Final decontamination and dispositioning of the LWHS shall be considered during design. This will most likely consist of flushing, disassembly, and loading into a $4 \times 4 \times 8$ box.

\subsubsection{DOE Regulations}

Refer to DOE 6430.1A, Sections 0205 and 1300-11.2, and DOE 435.1, as applicable.

\subsubsection{Miscellaneous Design Features}

Particular care must be exercised to ensure that equipment and components do not create conditions that could trap contamination and sludge. It is essential to eliminate inaccessible pockets, crevices, blind holes, and rough surfaces that could trap contamination. All equipment used in contaminated areas and power module enclosures must be able to withstand decontamination when sprayed with medium pressure water and/or wiped with cloths dampened by water soap, alcohol, or other nonhazardous materials.

The design and material selection shall include features that facilitate decontamination of equipment and the facility. Particular attention shall be paid to any equipment in high and very high radiation areas that may exist at the end of the facility's life.

\subsection{Operating Personnel and Services}

The operating procedures and requirements of the LWHS are not anticipated to present any significant safety or environmental risks under routine operation or maintenance.

The design and material selection shall include features that facilitate the operation of equipment and the facility.

Operation of the LWHS treatment and loadout systems will require 324 Building operators and radiological control support. 


\section{HNF-4412, Rev. 0}

\subsection{Testing}

Testing requirements for the transfer and treatment systems of the LWHS will be addressed in Acceptance Test Procedures and Operational Test Procedures per applicable requirements of HNF-PRO-1819. Design and specification reviews, followed by QA verification activities during equipment procurement, fabrication, and installation, should validate proper layout, material selection, and qualification testing. 


\subsection{CODES AND STANDARDS}

The following government documents, and industry standards documents shall be considered in the development of requirements for the design and fabrication of the 324 Building LWHS.

In addition to the items listed below, "National Consensus" codes and standards shall be incorporated when required by federal/state law or local codes. The latest editions/revision of all codes, standards, and manuals shall be used in the development of requirements.

\subsection{Government Documents}

10 CFR 20, Standards for Protection Against Radiation, Code of Federal Regulations.

10 CFR 830, Nuclear Safety Management, Code of Federal Regulations.

10 CFR 830.120, Quality Assurance, Code of Federal Regulations.

10 CFR 835, Occupational Radiation Protection, Code of Federal Regulations.

10 CFR 1021, NEPA Implementing Procedures, Code of Federal Regulations.

29 CFR 1910, Occupational Safety and Health Standards, Code of Federal Regulations.

29 CFR 1926, Safety and Health Regulations for Construction, Code of Federal Regulations.

40 CFR 61, National Emission Standards for Hazardous Air Pollutants, Subpart H, Code of Federal Regulations.

40 CFR Subchapter I, Subparts 260, 264, 265, and 270, Solid Wastes, Code of Federal Regulations.

40 CFR 1500-1508, NEPA Documentation, Code of Federal Regulations

DOE 5400.5, Radiation Protection of the Public and the Environment, U.S. Department of Energy, Washington, D.C.

DOE, 1997, Hazard Categorization and Accident Analysis Techniques for Compliance with DOE Order 5480.23, Nuclear Safety Analysis Reports, DOE-STD-1027-92, U.S. Department of Energy, Washington, D.C., December 1992.

DOE Order 5480.24, Nuclear Criticality Safety, U.S. Department of Energy, Washington, D.C. 
DOE Order 5480.28, Natural Phenomena Hazards Mitigation, U.S. Department of Energy, Washington, D.C.

DOE Order 5820.2A, Radioactive Waste Management, U.S. Department of Energy, Washington, D.C.

DOE Order 6430.1A, General Design Criteria, U.S. Department of Energy, Washington, D.C.

DOE-STD-1020, Natural Phenomena Hazards Design and Evaluation Criteria for Department of Energy Facilities, U.S. Department of Energy, Washington, D.C.

LLNL, Human Factors Design Guidelines for Maintainability of DOE Nuclear Facilities, UCRL-15673, Lawrence Livermore National Laboratory, Livermore, California.

WAC 173-303, Dangerous Waste Regulations, Department of Ecology, Olympia, Washington.

WAC197-11, State Environmental Policy Act, Department of Ecology, Olympia, Washington.

WAC-246-247, Radiation Protection - Air Emissions, Department of Health, Olympia, Washington

WAC 296-104, Board of Boiler Rules, Substantive, Department of Labor and Industries, Olympia, Washington.

WAC 296-46; 296-401, Rules and Regulations for Installing Electrical Wires and Equipment, Olympia, Washington

6.2 Industry Standards

ANSI/AWS, Structural Welding Code - Steel, ANSI/AWS D.1, American National Standards Institute and American Welding Society, Miami, Florida.

ASME B31.3, Process Piping, American Society of Mechanical Engineers, New York, New York.

ASME Section III, Boiler and Pressure Vessel Code, American Society of Mechanical Engineers, New York, New York.

ASME Section VIII, Boiler and Pressure Vessel Code, Rules for Construction of Pressure Vessels, American Society of Mechanical Engineers, New York, New York.

ASME Section IX, Boiler and Pressure Vessel Code, Qualification Standard for Welding and Brazing Procedures, Welders, Brazers, and Welding and Brazing Operators, American Society of Mechanical Engineers, New York, New York. 


\section{HNF-4412, Rev. 0}

ASME, Dimensioning and Tolerancing, Y14.5, American Society of Mechanical Engineers, New York, New York.

IES, IES Lighting Handbook Reference and Application, Illumination Engineering Society of North America, New York, New York

NFPA 69, Explosion Prevention Systems, ANSI/NFPA 69 National Fire Protection Association, Quincy, Massachusetts.

NFPA 70, National Electrical Code, ANSI/NFPA 70, National Fire Protection Association, Quincy, Massachusetts.

NFPA 101, Life Safety Code, ANSI/NFPA 101, National Fire Protection Association, Quincy, Massachusetts.

UBC, Uniform Building Code, UBC-94, International Conference of Building Officials, Whittier, California.

UL-508, Industrial Control Equipment, Underwriters Laboratories Inc. (UL) 


\subsection{REFERENCES}

H-3-20389, "Ventilation Schematic Arrgt. Basement \& First Floor," 324 Building Drawing H-3-20389, Pacific Northwest Laboratory, Richland, Washington.

FSP-242, "Engineering Drawing Requirements," B\&W Hanford Company, Richland, Washington.

FSP-444, "Vendor Information Requirements," B\&W Hanford Company, Richland, Washington.

HNF-IP-1264, "324 Facility Stabilization Project Administration Manual," B\&W Hanford Company, Richland, Washington.

HNF-IP-1277, "300 Area Radiological Control Procedures," B\&W Hanford Company, Richland, Washington.

HNF-MP-003, Integrated Environment Safety and Health Management System Plan, Fluor Daniel Hanford, Inc., Richland, Washington.

HNF-MP-599, Project Hanford Quality Assurance Program Description, Fluor Daniel Hanford, Inc., Richland, Washington.

HNF-PRO-088, Electrical Work Safety, Fluor Daniel Hanford, Inc., Richland, Washington.

HNF-PRO-089, Electrical Installation Safety, Fluor Daniel Hanford, Inc., Richland, Washington.

HNF-PRO-097, Engineering Design and Evaluation, Fluor Daniel Hanford, Inc., Richland, Washington.

HNF-PRO-427, Site Safeguards and Security Program Planning Requirements, Fluor Daniel Hanford, Inc., Richland, Washington.

HNF-PRO-704, Hazard and Accident Analysis Process, Fluor Daniel Hanford, Inc., Richland, Washington.

HNF-PRO-709, Preparation and Control Standards For Engineering Drawings, Fluor Daniel Hanford, Inc., Richland, Washington

HNF-PRO-1621, ALARA Decision Making Methods Fluor Daniel Hanford, Inc., Richland, Washington. 
HNF-PRO-1622, Radiological Design Review Process, Fluor Daniel Hanford, Inc., Richland, Washington.

HNF-PRO-1623, Radiological Work Planning Process, Fluor Daniel Hanford, Inc., Richland, Washington.

HNF-PRO-1633, ALARA Program Records, Fluor Daniel Hanford, Inc., Richland, Washington.

HNF-PRO-1819, PHMC Engineering Requirements, Fluor Daniel Hanford, Inc., Richland, Washington

HSRCM-1, Hanford Site Radiological Control Manual, Fluor Daniel Hanford, Inc., Richland, Washington.

BWHC, 1998, "324/327 Buildings Stabilization/Deactivation Project Project Management Plan," HNF-IP-1289, Rev. 2, B\&W Hanford Company, Richland, Washington, December 10, 1998.

BWHC, 1999, "324 Building Safety Analysis Report," HNF-SD-SPJ-SAR-001, Rev. 2, B\&W Hanford Company, Richland, Washington, August, 1999.

Carlstrom , R. F., 1996, "Safety Evaluation for Packaging (Onsite) Transport of LSA-II Liquids in MC-312 Cargo in Tanks," WHC-SD-TP-SEP-048, Rev. 0, Westinghouse Hanford Company, Richland, Washington, September 11, 1996.

DOE, 1998, "324 Building Radiochemical Engineering Cells, High-Level Vault, LowLevel Vault, and Associated Areas Closure Plan," DOE/RL-96-73, Rev. 1, U.S. Department of Energy, Richland Operations Office, Richland, Washington, March 25, 1998.

Hafla, E. R., 1999A, "324 Liquid Waste Handling System Treatment Skid Location," BWHC Letter ERH-99-001, E. R. Hafla to S. H. Norton, B\&W Hanford Company, Richland, Washington, March 2, 1999.

Hafla, E. R., 1999B, “324 D Cell Treatment Skid Evaluation,” BWHC Letter ERH-99002, E. R. Hafla to S. H. Norton, B\&W Hanford Company, Richland, Washington, June 2, 1999.

Gregonis, R. T., 1997, "324 Facility Fire Hazards Analysis," HNF-SD-HT-FHA-002, Rev. 0, B\&W Hanford Company, Richland, Washington, October 1, 1997.

Greenborg, J., 1999, "324 Building B-Cell Characterization Assay of Maximum Dispersible Radioactivity," HNF-4842, Rev. 0, Fluor Daniel Northwest, Inc., Richland, Washington, August 17, 1999. 
Ham, J. E., 1998, "324 Building Liquid Waste Handling and Removal System Project Plan," HNF-3133, Rev. OA, B\&W Hanford Company, Richland, Washington, August 27, 1998.

Hendrickson, D. E., 1999A, "324 Building Stabilization Decontamination Recommendations for the Liquid Waste Handling System," Letter COGEMA-981158 , D. E. Hendrickson, Cogema Engineering Corp. to J. E. Ham, B\&W Hanford Company, Richland, Washington, December 31, 1998.

Hendrickson, D. E., 1999B, "Characterization Strategy and Data Quality Objectives," Letter COGEMA-99-002, D. E. Hendrickson, Cogema Engineering Corp. to J. E. Ham, B\&W Hanford Company, Richland, Washington, January 4, 1999.

Hendrickson, D. E., 1999C, "324 Building Stabilization Transportation and Disposal Recommendations for the Liquid Waste Handling System," Letter COGEMA-99037, D. E. Hendrickson, Cogema Engineering Corp. to J. E. Ham, B\&W Hanford Company, Richland, Washington, January 12, 1999.

Hendrickson, et al, 1999, "B-Cell Dispersible Material Removal Engineering Trade Study," HNF-5065, Rev. 0, Cogema Engineering Corp., Richland, Washington, August 1999.

Hill, R. L., 1999, "Data Analysis and Radionuclide Scaling Factor for the B-Cell Waste Stream," HNF-4904, Rev. 0, B\&W Hanford Company, Richland, Washington, October 1999.

Hoffman, M. W., 1999, "324 Building Pre-Hazard Analysis Support for Liquid Waste Handing System," Letter CO-99-BWHC-105, Fluor Daniel Northwest, Inc. to J. E. Ham, B\&W Hanford Company, January 15, 1999.

O'Rourke, J. F., 1999, "Results of Film Removal Study on 324 Facility B-Cell Samples," HNF-4298, Rev. 1, Numatec Hanford Corporation, Richland, Washington, May $18,1999$.

Peters, B. B., 1999, "Liquid Waste Handling System Packaging Support Task," Letter WMNW-ENG-99-079, B. B. Peters, Waste Management Federal Services Northwest Operations, to J. E. Ham, B\&W Hanford Company, Richland, Washington, July 13, 1999.

Riddelle, J. G., 1999, "Chemical Wastes to be Expected From Decontamination pf 324 REC Facility," BWHC Letter JGR-99-012, J. G. Riddelle to D. S. Takasumi, B\&W Hanford Company, Richland, Washington, August 24, 1999.

Seay, J. M., 1997, "324 Facility Stabilization Project Administrative Manual," HNF-IP1264, Rev. 0, B\&W Hanford Company, Richland, Washington, June 25, 1997. 
Smith, R. J. 1998, "Safety Analysis Report for Packaging (Onsite) LR56/H Cask System," WHC-SD-TP-SARP-009, Rev. 0A, Waste Management Federal Services of Hanford, Inc., Richland, Washington, July 22, 1998.

Weiner, A. G., "Draft Environmental Requirements Checklist for 324 Building Liquid Waste Handling and Removal Project," Letter WMH-9858549, December 18, 1998, A. G. Weiner, Waste Management Federal Services of Hanford, Inc. to D. S. Takasumi, B\&W Hanford Company, Richland, Washington. 